\title{
Unit of Radioactive Decay
}

National Cancer Institute

\section{Source}

National Cancer Institute. Unit of Radioactive Decay. NCI Thesaurus. Code C77605.

An expression of the methodology chosed to describe the decay of radioactive substances. 